\title{
Pengaruh Penerapan Nilai-nilai Islami dan Komitmen Organisasional terhadap Kinerja Karyawan Pemasaran Bank Umum Syariah di Jawa Barat
}

\author{
Usep Deden Suherman \\ UIN Sunan Gunung Djati Bandung \\ email: usepds@uinsgd.ac.id
}

\begin{abstract}
Implementation of Islamic values is necessary for the development of the organization today, in order to impact organizational commitment and employee performance. The purpose of this study is is to determine and analyze the influence of Islamic values and organizational commitment to the performance of marketing employees of Sharia Commercial Bank in West Java. The method used is a descriptive and explanatory survey, by taking 100 samples of marketing employees, with sample accidental sampling technique and data analysis using path analysis. The research findings show that the implementation of Islamic values and organizational commitment partially or together have an impact on the performance of marketing employees of Sharia Commercial Bank in West Java. that the application of Islamic values and organizational commitment partially or together has an impact on the performance of marketing employees of Sharia Commercial Bank in West Java. Furthermore, the determinant value obtained is worth 0.892 , this gives the meaning that Islamic values and organizational commitment are able to explain the performance of marketing employees worth $89.2 \%$. Meanwhile, $10.8 \%$ was due to other factors.
\end{abstract}

Keywords: Islamic Values; Organizational Commitment; Employee Performance.

\begin{abstract}
Abstrak: Penerapan nilai-nilai Islami diperlukan dalam perkembangan organisasi saat ini, agar berdampak terhadap komitmen organisasional dan kinerja karyawan. Tujuan penelitian ini untuk mengetahui dan menganalisis pengaruh nilai-nilai Islami dan komitmen organisasional terhadap kinerja karyawan pemasaran Bank Umum Syariah di Jawa Barat. Metode yang digunakan adalah descriptive dan explanatory survey, dengan mengambil sampel 100 orang karyawan pemasaran, teknik sampel accidental sampling dan analisis data menggunakan path analysis. Dari penelitian ini ditemukan hasil bahwa penerapan nilai-nilai Islami dan komitmen organisasional secara parsial maupun bersama-sama mempunyai dampak terhadap kinerja karyawan pemasaran Bank Umum Syariah di Jawa Barat. Selanjutnya, nilai determinan diperoleh senilai 0.892, hal ini memberikan makna bahwa nilai-nilai Islami dan komitmen organisasional mampu menjelaskan kinerja karyawan pemasaran senilai 89,2\%. Sementara itu, senilai 10,8\% disebabkan oleh faktor lainnya.
\end{abstract}

Kata Kunci: Nilai-Nilai Islami; Komitmen Organisasional; Kinerja Karyawan.

Economica: Jurnal Ekonomi Islam - Volume 9, Nomor 1 (2018) 


\section{Pendahuluan}

Faktor sumber daya manusia (SDM) menjadi modal yang penting untuk mengembangkan dan memajukan suatu organisasi termasuk perusahaan. Oleh karena itu, maka pengaturan SDM yang baik pada organisasi bermanfaat untuk memujudkan visi dan misi perusahaan. Dengan kata lain, betapa pentingnya peran SDM dalam menentukan kesuksesan perusahaan. Hal tersebut mendorong perusahaan atau organisasi untuk memerhatikan SDM dari aspek kesejahteraan ataupun kinerja masing-masing karyawan. Untuk mengembangkan SDM yang bermutu maka diperlukan strategi yang tepat dalam mengatur dan sekaligus mengelola SDM dalam tubuh suatu perusahaan termasuk pengelolaan SDM pada perbankan konvensional maupun perbankan syariah dalam rangka menjawab tantangan-tantangan perubahan zaman yang semakin membutuhkan SDM yang bermutu dan berkualitas.

Perbedaan perbankan syariah dari perbankan konvensional adalah bahwa perbankan syariah harus lebih mampu menerapkan nilai-nilai Islami di dalam prosedur dan mekanisme kerjanya. Nilai-nilai Islam yang berasal dari prinsip-prinsip syariah tidak hanya menjadi simbol saja, tetapi harus teraplikasi secara nyata dalam setiap aktivitas perbankan syariah, dari mulai karyawan terendah sampai pada manajerial puncak, bahkan sampai pada nasabah bank syariah itu sendiri. Oleh karena itu, perbankan syariah dapat senantiasa berada dalam koridor nilai-nilai Islam guna mencapai pengembangan ke arah yang lebih baik lagi.

Menurut Musrin, nilai-nilai Islam ialah sekumpulan keyakinan diri, ilmuilmu tentang seperti apa manusia sebaiknya dalam menjalani aktivitas di dunia ini (Musrin 2004). Di antara nilai-nilai Islam yang perlu diterapkan dalam kegiatan perbankan syariah berdasarkan hukum perjanjian Islam antara lain, al-hurriyah (freedom), al-musāwah (persamaan atau kesetaraan), al-'adālah (keadilan), al- șidq (kebenaran dan kejujuran), al-rị̣ā (kerelaan), dan al-kitābah (tertulis). Al-ḥurriyah (kebebasan) ialah prinsip utama pada 
akad Islam dimana setiap orang dapat membuat kontrak. Al-Musāwah (persamaan atau kesetaraan) merupakan asas yang mengatur bahwa akad seseorang memiliki posisi serupa dari suatu perjanjian.

Penerapan nilai-nilai Islam pada bank syariah secara baik dan benar tentu saja akan memengaruhi keputusan masyarakat untuk menjadi nasabah bank syariah. Kepercayaan nasabah untuk menempatkan dananya ataupun untuk menggunakan pembiayaan dari perbankan syariah akan semakin meningkat. Dengan kata lain, mereka akan menjadi nasabah yang loyal pada bank syariah.

Penerapan nilai-nilai Islami pada diri karyawan pemasaran Bank Umum Syariah di Jawa Barat akan dapat meningkatkan kinerja karyawan. Hal ini dikarenakan nilai-nilai Islami merupakan pondasi dasar dalam melaksanakan suatu aktivitas atau pekerjaan yang berisi syariat-syariat Islam yang perlu dilakukan oleh seorang karyawan yang bekerja pada perusahaan. Kinerja karyawan menurut Mathis and Jackson dipengaruh oleh kemampuan individu untuk mengerjakan tugas, usaha yang dicurahkan dan adanya dukungan dari organisasi (Mathis and Jackson 2006).

Ada beberapa faktor yang memiliki dampak pada prestasi kerja karyawan, antara lain komitmen organisasi. Komitmen organisasi adalah perilaku yang digambarkan oleh seorang pegawai pada perusahaannyas dimana dia bekerja dengan tetap loyal dan setiap terhadap perusahaan serta tidak mau pindah ke perusahaan yang lainnya. Menurut Mathis dan Jackson, komitmen organisasional menggambarkan tingkatan dimana karyawan meyakini dan menerima visi organisasi dan memiliki keinginan untuk menetap dengan organisasi tersebut. Tidak adanya loyalitas karyawan pada organisasi maka rencana-rencana dan program organisasi sulit untuk direalisasikan sehingga komitmen organisasional ini sangat penting sekali diperhatikan oleh perusahaan. Adanya komitmen organisasional dari karyawan dapat mengatasi masalah-masalah seperti turnover, absensi dan lain sebagainya. Antara komitmen dengan kinerja memiliki hubungan yang 
positif artinya komitmen karyawan yang kuat akan dapat meningkatkan kinerja karyawan. Bahkan menurut Luthan, riset di masa lalu maupun sekarang menunjukkan korelasi di antara komitmen organisasi dan output yang diinginkan misalnya prestasi kerja yang baik, tingkat keluar masuk karyawan yang kurang dan absensi yang kurang. Oleh sebab itu, maka komitmen organisasional yang menjadi penyebab meningkatnya atau menurunnya kinerja karyawan.

Beberapa hasil penelitian menyatakan bahwa terdapat pengaruh nilainilai Islami terhadap kinerja karyawan seperti hasil penelitian dari Wahab (Wahab 2012) yang menyatakan bahwa nilai-nilai Islami memiliki dampak positif terhadap kinerja karyawan. Hasil penelitian tersebut didukung oleh Sakinah dan Adnan (Sakinah and Adnan 2016) yang menyatakan bahwa intellectual capital dan nilai-nilai Islami memiliki pengaruh terhadap kinerja. Selanjutnya, hasil penelitian dari Memari et al. (Memari, Mahdieh, and Marnani 2013) mengenai komitmen organisasional dengan kinerja karyawan menunjukkan korelasi yang positif. Hal tersebut sesuai dengan hasil penelitian Tolentino (Tolentino 2013) yang menyatakan hasil yang sama bahwa komitmen organisasional memiliki korelasi positif dengan peningkatan kinerja karyawan. Kedua hasil penelitian tersebut memiliki perbedaan dengan hasil penelitian Farah Abdi et al. (Abdi, Nor, and Radzi 2014) yang menyatakan bahwa komitmen organisasional tidak memiliki hubungan yang signifikan terhadap kinerja karyawan. Hal tersebut menjadi alasan kenapa penelitian tersebut menarik untuk diteliti.

Fenomena yang umumnya terjadi di Bank Umum Syariah khususnya di Jawa Barat ialah kurangnya komitmen karyawan terhadap organisasi yang ditandai dengan sering terjadinya keterlambatan dalam bekerja, terjadi turn over karyawan karena kurangnya loyalitas karyawan terhadap organisasi. Selain daripada itu, mengenai komitmen organisasional juga dapat dilihat pada tabel 1. berikut ini. 
Tabel 1. Jumlah Karyawan Bank Syariah di Jawa Barat

\begin{tabular}{|c|c|c|c|c|c|c|c|c|c|c|c|c|c|c|c|}
\hline \multirow{3}{*}{ Bank Syariah } & \multirow{3}{*}{$\begin{array}{c}\text { Jumlah } \\
\text { Pegawai } \\
\text { Sebelum } \\
\text { Tahun } \\
2010 \\
\end{array}$} & \multicolumn{13}{|c|}{ TAHUN } & \multirow[b]{3}{*}{$\%$} \\
\hline & & \multicolumn{2}{|c|}{2010} & \multicolumn{2}{|c|}{2011} & \multicolumn{2}{|c|}{2012} & \multicolumn{2}{|c|}{2013} & \multicolumn{2}{|c|}{2014} & \multicolumn{2}{|c|}{2015} & & \\
\hline & & $M$ & $\mathrm{~K}$ & $M$ & $\mathrm{~K}$ & $M$ & K & $M$ & $\mathrm{~K}$ & $M$ & $\mathrm{~K}$ & $M$ & $\mathrm{~K}$ & & \\
\hline BJB Syariah & 38 & 5 & 3 & 6 & 4 & 3 & 1 & 8 & 4 & 6 & 3 & 5 & 3 & 53 & 28.30 \\
\hline BCA Syariah & 31 & 5 & 3 & 3 & 0 & 3 & 3 & 4 & 3 & 5 & 3 & 4 & 2 & 41 & 24.39 \\
\hline BSM & 21 & 3 & 2 & 4 & 2 & 4 & 3 & 3 & 1 & 4 & 2 & 3 & 2 & 30 & 30.00 \\
\hline $\begin{array}{l}\text { BNI Syariah } \\
\text { Bank }\end{array}$ & 10 & 2 & 1 & 1 & 1 & 1 & 0 & 1 & 0 & 0 & 0 & 0 & 0 & 12 & 16.66 \\
\hline Muamalat & 13 & 1 & 0 & 1 & 0 & 1 & 1 & 1 & 0 & 0 & 1 & 0 & 1 & 14 & 7.14 \\
\hline TOTAL & & & & & & & & & & & & & & 150 & \\
\hline
\end{tabular}

Keterangan: $\mathrm{M}=$ Masuk, $\mathrm{K}=$ Keluar

Sumber : Data diolah dari Bank Syariah di Jawa Barat

Dari tabel 1. dapat dilihat bahwa sebelum tahun 2010 jumlah pegawai pada BJB Syariah adalah 38 dan mengalami peningkatan hingga tahun 2015 menjadi 53 orang atau kenaikan sebesar $28.30 \%$. Jumlah pegawai di BCA Syariah sebelum tahun 2010 berjumlah 31 orang, dan bertambah hingga tahun 2015 menjadi 41 orang atau naik sebesar 24.39\%. Pegawai di BSM sebelum tahun 2010 berjumlah 21 orang dan pada tahun 2015 menjadi 30 orang atau mengalami peningkatan sebesar $30.00 \%$. Di BNI Syariah sebelum tahun 2010, jumlah pegawai 10 orang dan mengalami peningkatan di tahun 2015 menjadi 12 orang naik sebesar 16.66\%. Pegawai di Bank Muamalat sebelum tahun 2010 berjumlah 13 orang, dan bertambah menjadi 14 orang pada tahun 2015 atau mengalami kenaikan sebesar 7.14\%.

Dari tabel 1. jelaslah bahwa kurangnya komitmen organisasional karyawan kepada perusahaan. Hal tersebut terjadi karena ada karyawan yang mengundurkan diri dan bergabung dengan perusahaan perbankan lainnya, pensiun dini, keluar karena diterima menjadi PNS dan mengundurkan diri tanpa alasan. Berbagai permasalahan tersebut menyebabkan penurunan kinerja karyawan sehingga menggangu terhadap pencapaian kinerja bank itu sendiri. Atas dasar itulah penelitian ini dilakukan untuk mengkaji pengaruh

Economica: Jurnal Ekonomi Islam - Volume 9, Nomor 1 (2018) http://journal.walisongo.ac.id/index.php/economica 
pengaruh penerapan nilai-nilai Islami dan komitmen organisasional terhadap kinerja karyawan pemasaran Bank Umum Syariah di Jawa Barat.

\section{Landasan Teori}

\section{Nilai-nilai Islami}

Islam sebagai risalah samawi yang universal datang untuk menangani kehidupan manusia dalam berbagai aspek, baik aspek spiritual maupun aspek material. Islam tidak hanya sebagai akidah, tetapi juga mencakup sistem politik, sosial budaya dan perekonomian yang ditujukan untuk seluruh manusia. Islam yang merupakan agama yang sempurna, dilengkapi dengan konsep dan sistem ekonomi yang dapat dipakai sebagai panduan manusia dalam melakukan kegiatan ekonomi.

Menurut Kamus Besar Ilmu Pengetahuan (Nusantara 2000) bahwa nilai (value) memiliki arti berguna, berdaya dan berlaku yang berasal dari bahasa latin, valere. Nilai merupakan sesuatu yang berharga yang dapat merubah sikap dan perilaku seseorang. Menurut Musrin (Musrin 2004), nilai-nilai Islam ialah sekumpulan prinsip hidup, ajaran mengenai seperti apa manusia sebaiknya melaksanakan kehidupannya di dunia ini. Sedangkan menurut Padmawati (Padmawati 2007), nilai-nilai Islam ialah sifat yang ada di dalam Al-Qur'an yang merupakan penentu sikap manusia yang bermanfaat bagi kemanusiaan yang digunakan sebagai bekal hidup di dunia dan akhirat.

Dari beberapa definisi di atas, maka nilai-nilai Islam merupakan sifat-sifat dari ajaran Islam yang bermanfaat bagi kemanusiaan. Nilai-nilai tersebut bukan hanya mengelola hubungan manusia dengan Allah akan tetapi hubungan antara manusia serta hubunganantara manusia dengan alam.

Rizk, dalam Shafique (Shafique et al. 2015) mengatakan bahwa etika kerja Islam merupakan komponen penting bagi setiap perusahaan dan karyawan dan staf bisa mendapatkan kebajikan melalui kode kerja Islam. Islam juga mengatakan kepada kita bahwa mengikuti nilai etika dalam setiap 
prospektus kehidupan sehingga Anda akan menjadi sukses. Menurut Rizk, etika Islam sebenarnya bersumber dari Al-Qur'an dan kehidupan Rasul saw. Menurut Abdul Malek dalam Salem dan Agil (Salem and Agil 2012), sumber nilai dalam Islam berbeda-beda. Jika kita maksudkan nilai-nilai Islam, maka sumbernya adalah Al-Qur'an dan Nabi Muhammad saw, dan ini berarti bahwa nilai-nilai harus mutlak dan stabil dan kebanyakan setiap Muslim mengikutinya. Menurut Salahudin et al. (Salahudin et al. 2016), etika Islam adalah prinsip benar dan salah untuk menunjukkan apa yang seharusnya dilakukan manusia dalam mengajarkan Al-Qur'an dan ditunjukkan dalam kehidupan agung Nabi Muhammad saw (Hashi 2011). Menurut Al-Aidaros et al. (Al-Aidaros, Shamsudin, and Idris 2013), etika kerja Islami bersifat komprehensif, realistis dan moderat. Etika dalam Islam tidak hanya moralitas agama dalam tindakan tertentu namun mencakup semua aspek kehidupan, baik fisik, spiritual, moral, bahkan dalam bentuk duniawi seperti intelektual, emosional, individual dan kolektif (Yaken 2006). Etika Islam berakar pada kitab suci Al-Qur'an dan Sunnah yang menyangkut nilai-nilai Islam, kepercayaan dan praktik (Arslan 2005) yang berisi sekumpulan moralitas yang berfungsi sebagai pembeda antara apa yang benar dengan apa yang salah (Beekun and Badawi 2005).

Abrahem (Abrahem 2001) menunjukkan bahwa ada beberapa nilai pribadi yang harus dipatuhi sebagai umat Islam saat kita melakukan pekerjaan. Hal ini berdasarkan tingkah laku utusan Allah sebagai teladan yang baik. Nilai-nilai ini berfungsi untuk memperbaiki lingkungan interaksi antarmanusia. Salah satu nilai penting adalah kesalehan. Dalam hal ini, Nabi saw menjelaskan bahwa "yang paling layak masuk surga adalah orang-orang saleh dan memiliki perilaku yang baik." Kepercayaan bisa dianggap sebagai kunci keimanan kepada Allah. Sebenarnya, tidak ada kepercayaan kepada mereka yang tidak memiliki kepercayaan. Adapun kejujuran, individu harus jujur dengan Tuhan dan dengan orang lain. Dalam hal ini, Nabi saw 
menjelaskan, "manusia masih jujur bahkan Allah menganggapnya kejujuran." (Salem and Agil 2012)

Menurut Hafidhuddin dan Tanjung (Hafidhuddin and Tanjung 2013), nilai yang ada harus membuahkan akhlakul karimah pada nilai suatu sikap. Nilai-nilai tersebut adalah:

a. al-Salāḥ (baik dan bermanfaat)

Salāh berarti sesuatu yang baik, berguna dan bermanfaat, maka secara istilah șalāḥ adalah segala perbuatan yang menggunakan daya yang dimiliki manusia, yang menghasilkan atau mendatangkan manfaat bagi pihak lain. Daya yang dimiliki tersebut berupa daya fisik yaitu tenaga dan upaya manusia, daya fikir yaitu pemikiran dalam segala tindakan, dan yang terakhir adalah daya batin yaitu berkaitan dengan emosi, perasaan dan hawa nafsu.

b. al-Itqān (kemantapan)

Mutu kerja yang itqān artinya sifat pekerjaan Tuhan, yang berarti rapi dan profesional. Sebuah pekerjaan disebut itqān apabila melakukan pekerjaaan tanpa cacat, menaati aturan tuntutan pekerjaan, tidak menundanunda pekerjaan dan tepat waktu, serta berpikir untuk bisa mengembangkan pekerjaan agar ada peningkatan.

c. al-Iḥsān (mengerjakan yang terbaik)

Mutu ihsān memiliki arti: Pertama, ihsān artinya "yang terbaik" dikerjakan. Kedua, ihsān memiliki arti "lebih baik" dari mutu pekerjaan sebelumnya. Atau bisa juga berupa balasan kebaikan yang sudah dikerjakan orang lain terhadap kita sendiri.

d. al-Mujāhadah (kerja keras dan optimal)

Makna mujāhadah yakni apabila seorang mukmin terserat dalam kemalasan, santai dan cinta dunia, maka ia harus memaksa dirinya melawan hawa nafsu tersebut dan bekerja lebih keras lagi dan optimal sebagaimana pekerjaan sebelumnya. 
e. Tanāfus dan Ta'āwun (berkompetisi dan tolong menolong)

Tanāfus yang berarti berkompetisi dan ta'āwun yang berarti saling membantu. Al-Qur'an dalam ayat-ayatnya menggambarkan persaingan dalam mutu amal saleh.

\section{f. Mencermati Nilai Waktu}

Berarti selalu memanfaatkan waktu dengan sebaik-baiknya dalam melaksanakan pekerjaan apa pun. Waktu yang ada digunakan untuk terus berprestasi dan mengharap ridha Allah swt. semata.

\section{g. SIFAT (Șidiq, Istiqāmah, Fațānah, Amānah, Tablīgh)}

Suatu sifat wajib bagi Rasul yang patut kita tauladani, yaitu : (1) Șidiq, berarti mempunyai kejujuran yang dilandasi dengan ucapan, keyakinan, serta perbuatan yang didasarkan pada ajaran Islam, (2) Istiqāmah, memiliki arti tetap dalam keimanan dan values yang sesuai walaupun berhadapan dengan banyak rintangan dari mana pun. (3) Fațānah, berarti sangat memahami secara mendalam segala sesuatu hal yang menjadi kewajiban sebagai manusia, (4) Amānah, yaitu bertanggung jawab dalam mengerjakan tugas dan pekerjaan. (5) Tabligh, artinya mendorong dan memberikan contoh-contoh pada orang lain dalam rangka mengerjakan pekerjaan sesuai ketetapan dalam agama islam

\section{Komitmen Organisasional}

Meyer dan Allen dalam Landry dan Vandenberghe (Landry and Vandenberghe 2009) menjelaskan "commitment is a global psychological state that characterizes the relationship between employees and organizations" (komitmen ialah situasi psikologis yang menggambarkan hubungan antara karyawan dengan organisasinya). Porter et al. dalam Limsila dan Ogunlana (Limsila and Ogunlana 2008) mendefinisikan kata "komitmen" sebagai kekuatan dari seorang individu yang diidentifikasikan dengan keikutsertaan dalam organisasi tertentu. Selanjutnya, Porter et al. 
mengemukakan bahwa komitmen mempunyai tiga komponen utama: kepercayaan (anggapan) kuat dan menerima tujuan dan nilai organisasi; suatu kesediaan untuk menggunakan daya dan upaya yang besar atas nama organisasi; dan kemauan terbatas untuk tetap menjadi anggota organisasi.

Mathis dan Jackson (Mathis and Jackson 2006) menjelaskan, "Organizational commitment is the degree to which employees believe in and accept organizational goals and desire to remain with the organization." Dari definisi ini maka komitmen organisasional merupakan suatu tingkatan sampai karyawan memiliki keyakinan dan menerima arah organisasi dan memiliki harapan menetap pada organisasi yang bersangkutan. Selanjutnya, Mathis dan Jackson (Mathis and Jackson 2006) mengemukakan orang yang memiliki kepuasan terhadap pekerjaannya maka akan memiliki komitmen pada organisasi dan orang yang memiliki komitmen pada organisasi akan memperoleh kepuasan yang lebih besar lagi.

Robbins dan Judge (Robbins and Judge 2009) menggambarkan komitmen organisasional dengan "a state in which an employee identifies with a particular organization and its goals and wishes to maintain membership in the organization." Dari pernyataan di atas maka komitmen organisasional merupakan kondisi dimana karyawan berpihak pada tujuantujuan organisasi tertentu dan memiliki minat menjaga keanggotaan pada organisasi tersebut. Selanjutnya, ia menekankan pada keberpihakan karyawan terhadap organisasi dan kesungguhan karyawan terhadap pencapaian tujuan organisasi serta upaya karyawan untuk tetap bertahan.

Pengertian yang agak berbeda diungkapkan oleh McShane dan Glinow (McShane and Glinow 2005) yang mengatakan bahwa "organizational commitment refers to the employee's emotional attachment to, identification with, and involvement in a particular organization." Dari definisi di atas, komitmen organisasional merupakan pernyataan emosi karyawan yang digambarkan dengan keikutsertaan karyawan pada organisasi tertentu. 
Greenberg (Greenberg 2005) menjelaskan komitmen organisasional sebagai "the concept of organizational commitment is concerned with the degree to which people are involved with their organization and are interested in remaining a part of them." Konsep komitmen organisasional menggambarkan tingkat keikutsertaan orang pada organisasi mereka dan sangat tertarik menjadi bagian dari diri organisasi tersebut. Sedangkan, Kreitner \& Kinicki (Kreitner and Kinicki 2005) mengemukakan bahwa komitmen organisasional menunjukkan seperti apa individu menggambarkan dirinya pada organisasi dan merasa terikat pada arah organisasi. Komitmen organisasional juga didefinisikan sebagai ikatan emosional terhadap organisasi di mana karyawan berkomitmen kepada organisasi (Qureshi et al. 2011).

Komitmen organisasional digambarkan sebagai afeksi psikologis dan pengabdian yang dimiliki karyawan terhadap organisasi (Dixon 2012). Baek (Baek 2012) mengemukakan bahwa "Organizational commitment is defined as a strong desire to remain a member of a particular organization; a willingness to exert high levels of effort on behalf of the organization; a definite belief in, and acceptance of, the values and goals of the organization." Dari pernyaataan ini maka komitmen organisasional ialah karyawan yang tetap berkeinginan untuk menjadi bagian dari organisasi tempatnya bekerja dan sangat bersedia menerima semua nilai-nilai dan tujuan organisasi.

Berdasarkan pada definisi di atas maka penulis menyimpulkan bahwa komitmen organisasional merupakan sikap dan perilaku seorang karyawan yang tetap berkenginan bekerja pada organisasi dengan siap menerima segala aturan dan tugas-tugas yang diberikan oleh organisasi atau perusahaan.

Dimensi komitmen organisasional dikemukakan oleh Meyer dan Allen dalam Luthan (Luthans 2008) yaitu sebagai berikut:

1. Komitmen afektif ialah bentuk perasaan emosional karyawan dalam menggambarkan keikutsertaannya pada organisasi. Menurut Georges 
Yachouchi (Yahchouchi 2009) indikator dari komitmen afektif ini adalah bangga menjadi bagian perusahaan, bangga terhadap perusahaan, usaha ekstra, peduli akan nasib perusahaan, dan senang memilih perusahaan sebagai tempat bekerja.

2. Komitmen kontinuens. Menurut Georges Yachouchi (Yahchouchi 2009) indikator komitmen kontinuens adalah kesesuaian dengan kebijakan perusahaan mengenai karyawan, loyalitas pada perusahaan, alternatif pekerjaan, keuntungan yang didapat apabila bekerja sangat lama, perubahan jika meninggalkan perusahaan, keputusan kerja pada perusahaan adalah keputusan yang salah.

3. Komitmen normatif. Menurut Georges Yachouchi (Yahchouchi 2009) indikator komitmen normatif adalah kecocokan dengan norma-norma perusahaan, perusahaan merupakan yang terbaik sebagai tempat kerja, penerimaan semua tipe pekerjaan, perusahaan sebagai sumber inspirasi.

Sementara itu, berdasarkan model komitmen Meyer and Allen maka Ling, Fang dan Zhang dalam Chui (Chui 2007) menyebut lima model komitmen yaitu sebagai berikut:

a. Komitmen afektif mengacu pada identifikasi dengan dan lampiran ke unit kerja (atau organisasi).

b. Komitmen normatif mengacu pada sikap untuk dan kinerja di unit (atau organisasi) berdasarkan norma-norma sosial dan etnis profesional.

c. Komitmen ideal merupakan penekanan pada pengembangan pribadi dan realisasi dari inspirasi.

d. Komitmen ekonomi disebut tinggal dengan unit (atau organisasi) karena takut kerugian ekonomi.

e. Komitmen pilihan disebut dengan tinggal bersama unit (atau organisasi) karena kegagalan mencari pekerjaan lebih baik. 
Pengaruh Penerapan Nilai-nilai Islami...

\section{Kinerja Karyawan}

Kinerja karyawan menurut Bernardin dan Russell (Bernardin and Russell 2010) ialah keseluruhan hasil kerja yang diselesaikan selama periode waktu tertentu. Robbins dan Judge (Robbins and Judge 2009) menyatakan bahwa kinerja karyawan ialah fungsi yang menggambarkan hubungan antara kompetensi, dorongan dan kesempatan untuk menunjukkan kinerja organisasi. Kinerja karyawan menurut Mathis dan Jackson (Mathis and Jackson 2006) ialah faktor yang memengaruhi seberapa besar karyawan memberikan manfaat pada organisasi. Dengan demikian kinerja ialah pencapaian kerja yang diperoleh pegawai yang dinilai baik secara mutu maupun jumlah dalam rangka memperoleh tujuan organisasi.

Dimensi kinerja karyawan menurut Bernardin dan Russell (Bernardin and Russell 2010) di antaranya adalah sebagai berikut:

1. Kualitas output, ialah sejauhmana hasil pelaksanaan aktivitas mendekati tujuan yang diharapkan oleh organisasi atau mengerjakan aktivitas melalui cara yang sesuai dengan tujuan yang ditetapkan.

2. Kuantitas output, ialah keseluruhan jumlah yang diperoleh dari segala aktivitas yang telah dikerjakan.

3. Ketepatan waktu, ialah sejauhmana kegiatan atau aktivitas dapat diselesaikan dalam waktu lebih cepat dari yang ditetapkan oleh organisasi.

4. Keefektifan biaya, ialah sejauhmana pemakaian sumber organisasi yang meliputi sumber daya manusia, keuangan, teknologi, material yang dimaksimalkan untuk memperoleh sasaran sesuai dengan yang telah ditetapkan.

5. Kebutuhan untuk pengawasan, ialah sejauhmana pegawai mampu mengerjakan suatu pekerjaan tanpa diawasi dengan ketat yang ditujukan untuk mencegah segala tindakan atau perilaku yang tidak diharapkan. 
6. Dampak hubungan pribadi, ialah sejauhmana pegawai dapat bekerjasama dengan rekan kerja dan bawahan yang menunjukkan pula perasaan harga diri dan nama baik.

Etika kerja dan komitmen organisasi saling terkait satu sama lain dan mendapat banyak perhatian (Yousef 2001). Menurut Ooi dan Arumugam (Ooi and Arumugam 2006), untuk mencapai komitmen organisasi, atasan membantu karyawan mereka dan memberi mereka nilai. Jika dukungan organisasi lebih baik daripada karyawan tetap tinggal dengan organisasi (Shafique et al. 2015)

\section{Pengaruh Nilai-nilai Islami terhadap Kinerja Karyawan}

Nilai-nilai Islami merupakan bagian dari pembentuk budaya dan kebiasaan manusia pada umumnya, begitu pula dengan nilai-nilai Islam bisa ditemukan pada perusahaan. Nilai-nilai Islam ini menjadi pedoman perilaku dalam berorganisasi atau bekerja yang dilakukan dengan tujuan ibadah dan hanya semata mengharap ridha Allah swt, sehingga dalam bekerja apabila menerapkan nilai-nilai Islam akan memberikan semangat kerja yang tinggi pada karyawan dan menghasilkan tercapainya tujuan perusahaan dan kemajuan secara optimal.

Beberapa hasil penelitian menunjukkan bahwa penerapan nilai-nilai Islami memiliki pengaruh terhadap kinerja karyawan seperti hasil penelitian dari Hadisi (Hadisi 2014) yang menyatakan bahwa etika kerja Islam mempunyai dampak pada kinerja karyawan pada sektor perusahaan multinasional. Hasil penelitian tersebut sesuai dengan hasil penelitian Wahab (Wahab 2012) yang menyatakan bahwa nilai-nilai Islami memiliki dampak positif terhadap kinerja karyawan. Environ juga menyatakan hal yang sama bahwa intellectual capital dan nilai-nilai Islami memiliki pengaruh terhadap kinerja. Oleh sebab itu, maka nilai-nilai Islami memiliki dampak positif pada peningkatan kinerja karyawan. 


\section{Pengaruh Komitmen Organisasional terhadap Kinerja Karyawan}

Komitmen organisasional dibutuhkan untuk mengukur kinerja karyawan. Untuk mencapai kinerja yang optimal karyawan juga harus memiliki komitmen yang baik terhadap organisasinya. Para peneliti telah menunjukkan bentuk-bentuk komitmen organisasi ditujukan untuk memprediksi, untuk berbagai derajat, sejumlah perilaku, termasuk niat untuk tinggal, pergantian, kinerja, absensi, stres, dan kesehatan (Meyer et al. 2002). Pernyataan di atas memperjelas bahwa komitmen organisasional berkaitan dengan sejumlah perilaku termasuk juga kinerja karyawan. Selanjutnya, hasil penelitian dari Memari (Memari, Mahdieh, and Marnani 2013) mengenai komitmen organisasional dengan kinerja karyawan juga menunjukkan korelasi yang positif. Kemudian hasil penelitian dari Hafiz (Hafiz AZ 2017) mengungkapkan hasil yang serupa dimana komitmen organisasional memiliki pengaruh terhadap kinerja karyawan. Didukung pula oleh hasil penelitian Tolentino (Tolentino 2013) yang menyatakan bahwa komitmen organisasional memiliki korelasi positif dengan peningkatan kinerja karyawan. Dengan demikian, maka komitmen organisasional memiliki korelasi yang positif terhadap peningkatan kinerja karyawan.

\section{Kerangka Pemikiran}

Pemahaman nilai-nilai Islami dapat diterapkan dalam kehidupan seharihari bukan hanya di perusahaan semata. Nilai-nilai Islami tersebut akan membentuk kepribadiaan seseorang. Rivai dan Buchari (Rivai and Buchari 2009) mengemukakan bahwa pembinaan mutu personalitas seorang muslim supaya mengerti dengan benar mengenai nilai Islam dan diharapkan dapat memberi dampak perubahan yang positif pada kehidupan di sekelilingnya.

Nilai-nilai Islami dan komitmen organisasional memiliki kaitan erat dengan peningkatan kinerja karyawan. Terdapat temuan riset yang mengemukakan bahwa nilai-nilai Islami dan komitmen organisasional mempunyai dampak pada kinerja karyawan seperti penelitian Wahyudi 
(Wahyudi 2015) dimana komitmen organisasional dan etika kerja islam memiliki dampak yang signifikan terhadap kinerja karyawan. Awan et al. (Awan et al. 2014) menyatakan ada korelasi positif antara etika kerja islam, kinerja karyawan yang dimoderasi komitmen organisasional. Oleh sebab itu, kerangka pemikiran dapat dilihat dalam Gambar 1.

Gambar 1. Kerangka Pemikiran

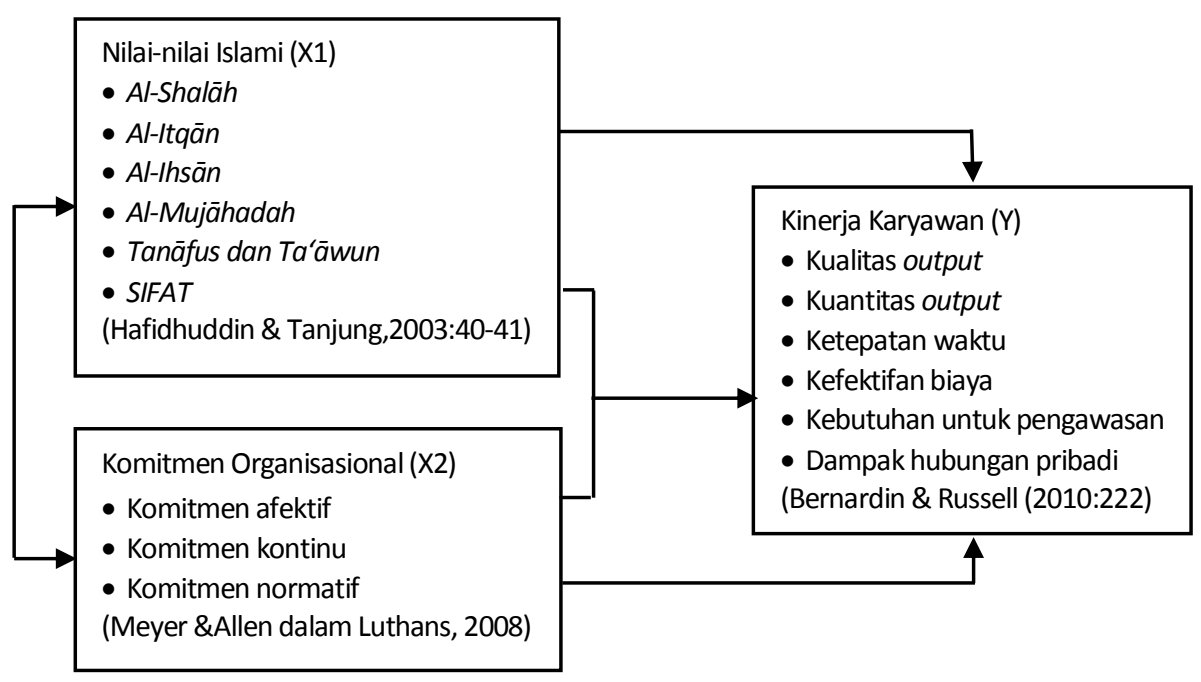

\section{Metode Penelitian}

Penelitian ini bersifat deskriptif dan explanatory survey. Variabel yang digunakan dalam penelitian ini ialah nilai-nilai Islami dan komitmen organisasional yang merupakan variabel independen dan kinerja pegawai yang merupakan variabel dependen. Populasi dalam penelitian ini ialah karyawan bagian pemasaran Bank Syariah di Jawa Barat yang terdiri dari Bank Muamalat, BJB Syariah, BRI Syariah, BCA Syariah, Bank Mega Syariah, Bank Syariah Mandiri, BNI Syariah, Bank Bukopin Syariah dan Bank Panin Syariah. Sedangkan sampel yang diambil ialah 100 orang karyawan bagian pemasaran dari 10 Bank Syariah di Jawa Barat di atas. Masing-masing dari 
bank tersebut diambil 11 orang karyawan. Adapun pengukuran variabel dapat diuraikan pada tabel 2 .

Tabel 2. Operasionalisasi Variabel Penelitian

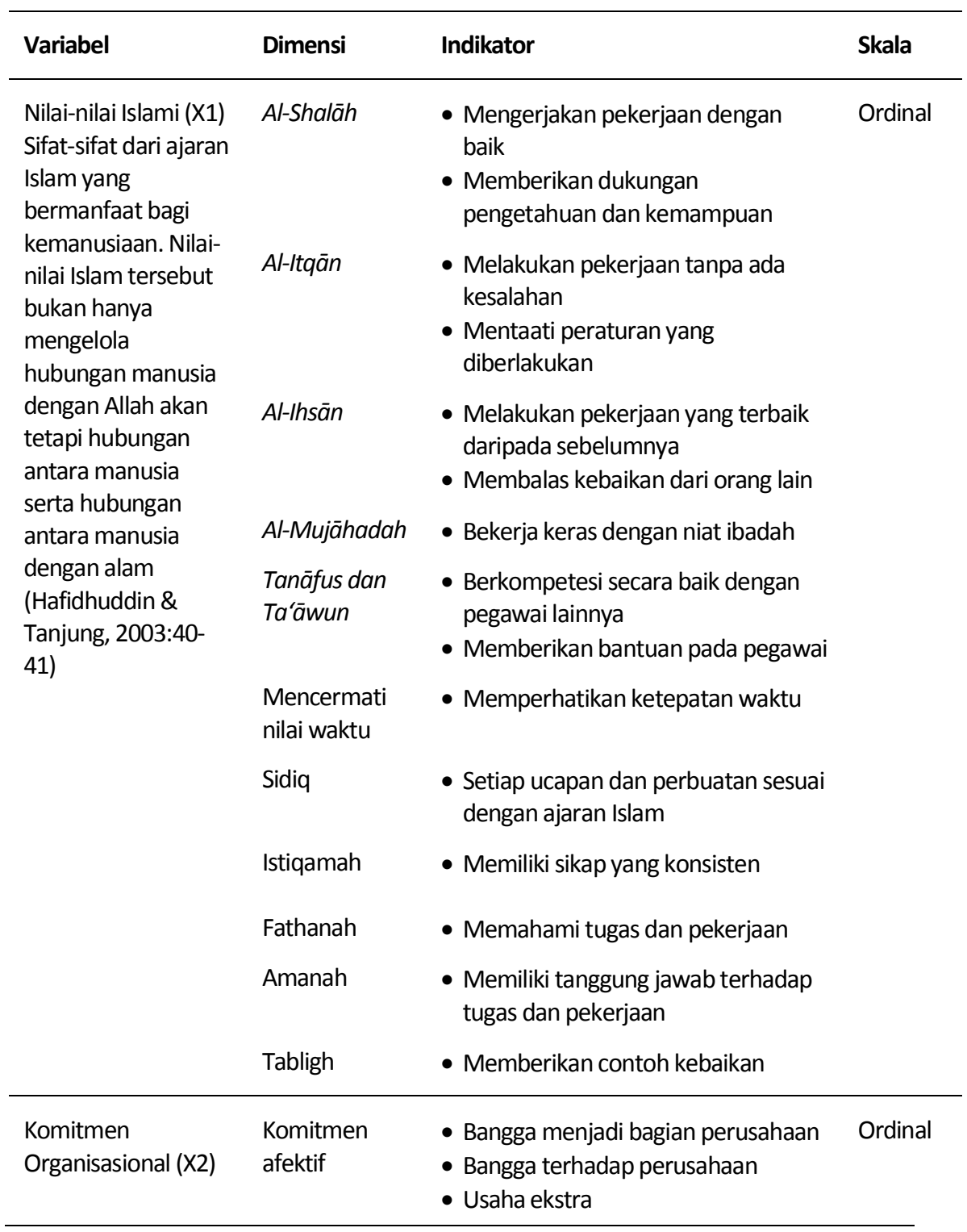

Economica: Jurnal Ekonomi Islam - Volume 9, Nomor 1 (2018) 
Usep Deden Suherman

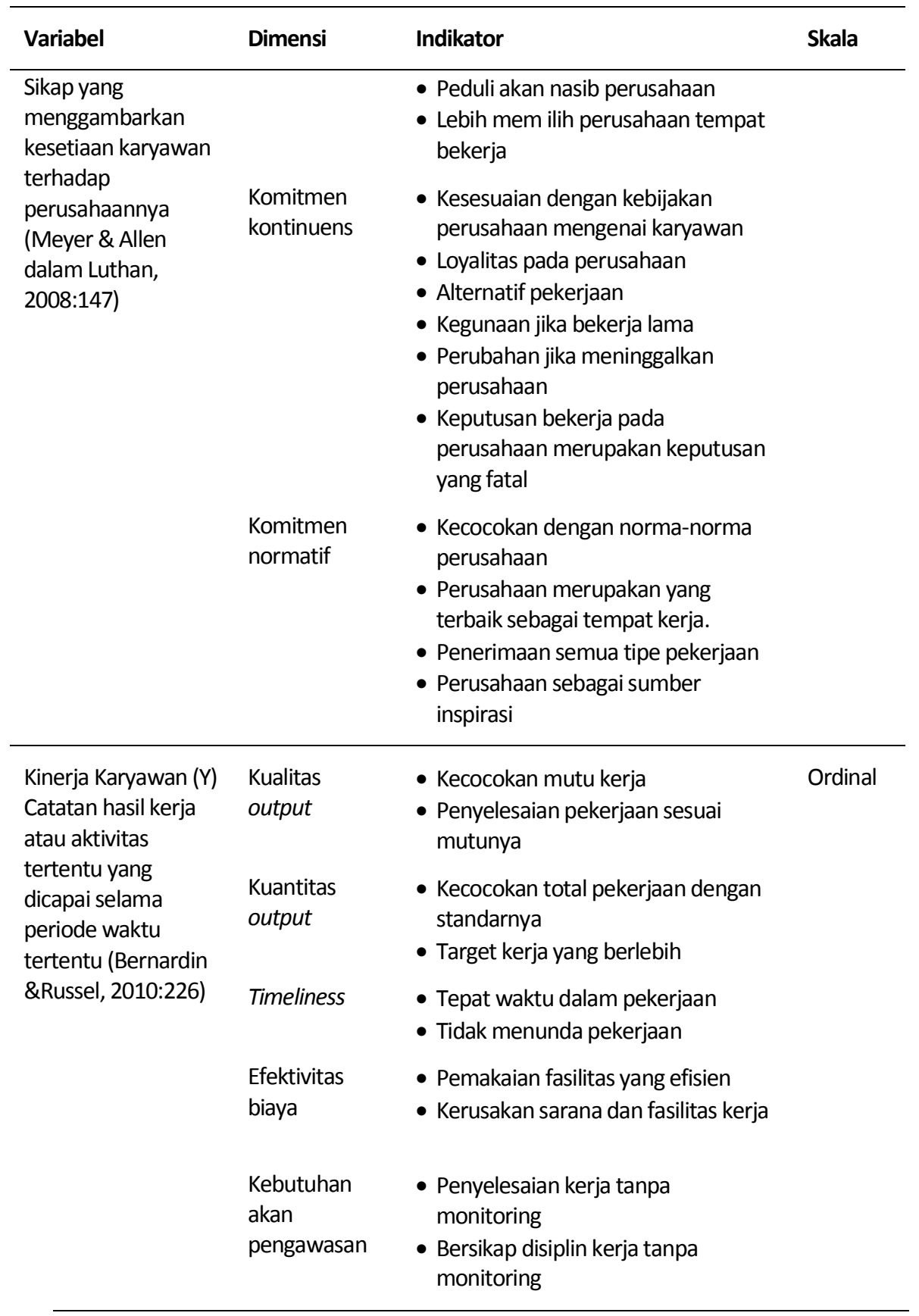




\begin{tabular}{llll}
\hline Variabel & Dimensi & Indikator & Skala \\
\hline Dampak & • Hubungan pegawai dalam bekerja & \\
interpersonal & • Kerjasama dalam bekerja \\
& $\bullet$ Memberikan solusi bersama & \\
& \\
\hline
\end{tabular}

Pengambilan sampel dilakukan dengan menggunakan teknik sampel accidental sampling yang termasuk teknik nonprobability sampling. Accidental sampling adalah metode penentuan sampel berdasarkan kebetulan. Adapun teknik pengumpulan data dalam penelitian ini ialah observasi, kuesioner dan wawancara. Sedangkan teknik analisis data dalam penelitian ialah menggunakan analisis jalur.

\section{Hasil dan Pembahasan}

Hasil penelitian menunjukkan bahwa secara simultan terdapat pengaruh penerapan nilai-nilai Islami dan komitmen organisasional terhadap kinerja karyawan pemasaran yaitu senilai 89,2\%. Artinya bahwa 89,2\% perubahan pada kinerja karyawan pada Bank Umum Syariah di Jawa Barat disebabkan oleh penerapan nilai-nilai Islami dan komitmen organisasional dan sebesar 10,8\% kinerja karyawan dipengaruhi oleh variabel lain.

Hasil penelitian ini sesuai dengan hasil penelitian Wahyudi (Wahyudi 2015) yang menyatakan bahwa komitmen organisasional dan etika kerja Islam memiliki dampak yang signifikan terhadap kinerja karyawan. Hasil tersebut didukung pula oleh hasil penelitian Awan et al. (Awan et al. 2014) yang menyatakan bahwa terdapat hubungan positif antara etika kerja Islam, kinerja karyawan yang dimoderasi oleh komitmen organisasional. Dengan demikian dapat disimpulkan bahwa penerapan nilai-nilai Islami dan komitmen organisasional memiliki dampak positif dalam peningkatan kinerja karyawan.

Economica: Jurnal Ekonomi Islam - Volume 9, Nomor 1 (2018) http://journal.walisongo.ac.id/index.php/economica 
Usep Deden Suherman

Tabel 3. Pengaruh Simultan

\begin{tabular}{lllll}
\hline Model & $\mathrm{R}$ & R Square & $\begin{array}{l}\text { Adjusted } \mathrm{R} \\
\text { Square }\end{array}$ & $\begin{array}{l}\text { Std. Error of the } \\
\text { Estimate }\end{array}$ \\
\hline 1 &, $944^{\mathrm{a}}$ &, 892 &, 889 & 2,51688 \\
\hline
\end{tabular}

Sumber : Output SPSS

Untuk menguji pengaruh secara simultan maka hipotesis dalam pengujian tersebut yaitu;

$\mathrm{H} 0$ : $\mathrm{P}_{\mathrm{YX} 1}=0$ Penerapan nilai-nilai Islami dan komitmen organisasional secara bersama-sama tidak mempunyai dampak pada kinerja karyawan.

Ha $: \mathrm{P}_{\mathrm{YX} 1} \neq 0$ Penerapan nilai-nilai Islami dan komitmen organisasional secara bersama-sama mempunyai dampak pada kinerja karyawan

Kemudian dilakukan uji F dengan rumus sebagai berikut:

$$
\begin{aligned}
& F=\frac{(n-k-1) R^{2}{ }_{y x 1 x 2}}{K\left(1-R^{2}{ }_{y x 1 x 2}\right)} \\
& F=\frac{(100-2-1) x 0,892}{2 x(1-0,892)} \\
& =399,36
\end{aligned}
$$

Tabel 4. Hasil Uji F

\begin{tabular}{lcc}
\hline Variabel & F hitung & F tabel \\
\hline $\begin{array}{l}\text { Nilai-nilai Islami } \\
\begin{array}{l}\text { Komitmen organisasional } \\
\text { Kinerja karyawan }\end{array}\end{array}$ & 399,360 & 3,0943 \\
\hline
\end{tabular}

Sumber: Data diolah (2018) 
Pada tabel 4. dihasilkan nilai $\mathrm{F}_{[0,05: 97]}=399,60$. Oleh karena nilai $\mathrm{F}_{\text {hitung }}>$ $F_{\text {tabel }}=3,0943$ yang berarti bahwa hipotesis nol tidak diterima. Oleh sebab itu, maka secara simultan penerapan nilai-nilai Islami dan komitmen organisasional memiliki dampak pada kinerja karyawan.

Hasil pengujian secara bersama-sama memberikan hasil yang positif dan signifikan. Hal ini memberikan arti bahwa nilai-nilai Islami dan komitmen organisasional memiliki dampak positif dan sangat berarti dalam meningkatkan kinerja karyawan. Penerapan nilai-nilai Islami yang kuat pada karyawan dan penguatan komitmen organisasional dapat meningkatkan kinerja karyawan.

Setelah melakukan pengujian simultan maka langkah berikutnya ialah melakukan pengujian secara parsial. Untuk melakukan pengujian parsial tersebut maka digunakan uji t yaitu sebagai berikut:

$$
t_{1}=\frac{P_{y x i}}{\sqrt{\frac{\left(1-R_{y}^{2}(x 1 \times 2)\right) x C r_{i i}, i=1,2}{n-k-1}}}
$$

\section{Pengaruh Penerapan Nilai-nilai Islami terhadap Kinerja Karyawan}

Rumusan Hipotesis :

H0 $: P_{Y X 1}=0$ Penerapan nilai-nilai Islami tidak mempunyai pengaruh terhadap kinerja karyawan.

Ha: $P_{Y X 1} \neq 0 \quad$ Penerapan nilai-nilai Islami mempunyai pengaruh terhadap kinerja karyawan.

Statistik uji:

$$
t_{1}(X 1)=\frac{0,856}{\sqrt{\frac{(1-0,892) \times 3,3028}{100-2-1}}}=24,067
$$

Economica: Jurnal Ekonomi Islam - Volume 9, Nomor 1 (2018)

http://journal.walisongo.ac.id/index.php/economica 
Kriteria uji Tolak H0 jika t hitung > t tabel dimana dari t tabel untuk taraf kepercayaan 0,05 serta degree of fredom $(2 ; 93)$ didapat nilai t tabel senilai 1,985 sebab nilai t hitung $(24,067)>t$ tabel $(1,985)$, maka pada tingkat kepercayaan 95\% H0 ditolak dan Ha diterima. Kesimpulannya ialah secara parsial penerapan nilai-nilai Islami mempunyai pengaruh terhadap kinerja karyawan pemasaran. Oleh karena itu, nilai-nilai Islami yang diterapkan pada karyawan mempunyai dampak positif dan sangat berarti dalam meningkatkan kinerja karyawan. Dengan demikian maka kinerja karyawan dapat ditingkatkan melalui penerapan nilai-nilai Islami pada karyawan melalui penerapan budaya kerja secara Islami sehingga karyawan dapat memiliki kesadaran terhadap kewajibannya pada perusahaan.

Hasil penelitian ini memiliki kesamaan dengan penelitian Hadisi (Hadisi 2014) yang menyatakan hal serupa bahwa etika kerja Islam mempunyai dampak pada kinerja karyawan pada sektor perusahaan multinasional. Selaras juga dengan hasil penelitian Wahab (Wahab 2012) yang menyatakan bahwa nilai-nilai Islami memiliki dampak positif terhadap kinerja karyawan. Demikian pula sejalan dengan penelitian Sakinah dan Adnan (Sakinah and Adnan 2016) yang menyatakan bahwa intellectual capital dan nilai-nilai Islami memiliki pengaruh terhadap kinerja.

Pemahaman atas nilai-nilai Islami terutama terkait dengan konsep kerja akan meningkatkan ketundukan dan kepatuhan pegawai atas perintah dan larangan Allah swt. Bekerja akan dilakukan dengan niat tidak hanya mencari kelimpahan materi tetapi juga untuk mencari keridaan Allah. Niat bekerja tidak hanya untuk mengejar kekayaan dunia tetapi juga untuk mencapai kebahagiaan di akhirat kelak. Pemahaman atas nilai-nilai agama dapat berdampak pada sikap dan perilaku pegawai dalam melaksanakan pekerjaan. 
Pengaruh Penerapan Nilai-nilai Islami...

\section{Pengaruh Komitmen Organisasional terhadap Kinerja Karyawan}

Rumusan Hipotesis :

$\mathrm{H} 0: \mathrm{P}_{\mathrm{yx} 2}=0 \quad$ Komitmen organisasional tidak memiliki pengaruh terhadap kinerja karyawan.

Ha:Pyx $2 \neq 0 \quad$ Komitmen organisasional memiliki pengaruh terhadap kinerja karyawan.

Statistik uji:

$$
t_{1}(X 2)=\frac{0,200}{\sqrt{\frac{(1-0,892) \times 3,3028}{100-2-1}}}=5,625
$$

Kriteria uji Tolak $\mathrm{H} 0$ jika $t$ hitung $>\mathrm{t}$ tabel dimana dari $\mathrm{t}$ tabel memiliki untuk taraf kepercayaan 0,05 serta degree of fredom $(2 ; 93)$ diperoleh nilai $t$ tabel senilai 1,985. Karena nilai t hitung $(5,625)>t$ tabel $(1,985)$, maka pada tingkat kepercayaan 95\% H0 tidak diterima dan Ha diterima. Oleh sebab itu, komitmen organisasional mempunyai pengaruh terhadap kinerja karyawan. Hal tersebut dapat diartikan bahwa komitmen organisasional karyawan mempunyai dampak positif dan sangat berarti dalam meningkatkan kinerja karyawan. Dengan demikian maka kinerja karyawan dapat ditingkatkan melalui penguatan komitmen afektif, kontinyu dan normatif pada karyawan sehingga karyawan tidak memiliki keinginan dan hasrat untuk pindah ke perusahaan lainnya.

Hasil penelitian ini sesuai dengan hasil penelitian Memari (2013:164) mengenai komitmen organisasional dengan kinerja karyawan yang menunjukkan korelasi yang positif. Hasil penelitian Hafiz (2017:7) mengungkapkan hasil yang serupa dimana komitmen organisasional memiliki pengaruh terhadap kinerja karyawan. Didukung pula hasil penelitian Tolentino (2013:51) yang menyatakan bahwa komitmen 
organisasional mempunyai hubungan positif dengan peningkatan kinerja karyawan.

Nilai dari dampak langsung dan dampak tidak langsung dari penerapan nilai-nilai Islami disajikan dalam table 5.

Tabel 5. Dampak X1 terhadap Y

\begin{tabular}{|c|c|}
\hline Dampak X1 terhadap Y & Nilai \\
\hline $\begin{array}{l}\text { Dampak } X_{1} \text { terhadap } Y \text { langsung } \\
\text { pyx }_{1} . \text { pyx }_{1}\end{array}$ & 0,733 \\
\hline $\begin{array}{l}\text { Dampak } X_{1} \text { terhadap } Y \text { melalui } X_{2} \\
\text { pyx } 1 . \mathrm{rx}_{1} \cdot \mathrm{X}_{2} \cdot \mathrm{py} \mathrm{x}_{2}\end{array}$ & 0,059 \\
\hline Jumlah & 0,792 \\
\hline
\end{tabular}

Sumber: Data diolah (2018)

Tabel 5. memperlihatkan bahwa pengaruh langsung penerapan nilainilai Islami pada kinerja karyawan pemasaran ialah sebesar 73,3\% dan pengaruh tidak langsung penerapan nilai-nilai Islami pada kinerja karyawan pemasaran melalui komitmen organisasional adalah sebesar 5,9\%. Hal ini menunjukkan bahwa sebesar 73,3\% kinerja karyawan dipengaruhi oleh nilainilai Islami secara langsung dan senilai 5,9\% dipengaruhi secara tidak langsung oleh komitmen organisasional. Keseluruhan pengaruh penerapan nilai-nilai Islami terhadap kinerja karyawan pemasaran Bank Umum Syariah di Jawa Barat ialah sebesar 79,2\% dengan arah positif. Artinya penerapan nilai-nilai Islami yang baik akan berdampak pada kinerja karyawan yang menjadi lebih baik lagi. Oleh sebab itu, kinerja karyawan dipengaruhi oleh penerapan nilai-nilai Islami secara keseluruhan senilai 79,2\%. Jadi 20,8\% sisanya dipengaruhi oleh faktor lainnya. Dengan demikian, nilai-nilai Islami perlu diterapkan pada diri seorang karyawan sehingga dengan adanya nilainilai Islami karyawan akan menyadari terhadap pentingnya kewajiban 
karyawan pada perusahaan. Dengan kesadaran tersebut maka karyawan pun akan memiliki kinerja yang baik.

Tabel 6. Pengaruh $\mathrm{X}_{2}$ terhadap $\mathrm{Y}$

\begin{tabular}{lc}
\hline Dampak X2 terhadap Y & Nilai \\
\hline $\begin{array}{l}\text { Dampak } X_{2} \text { terhadap Y langsung } \\
\text { pyX2. pyx2 }\end{array}$ & 0,04 \\
$\begin{array}{l}\text { Dampak } X_{2} \text { terhadap Y melalui } X_{1} \\
\text { pyx } 1 . X_{1} \cdot X_{2} \cdot p y x_{2}\end{array}$ & 0,059 \\
\hline Jumlah & 0,099 \\
\hline
\end{tabular}

Sumber: Data diolah (2018)

Tabel 6. memperlihatkan bahwa pengaruh langsung komitmen organisasional terhadap kinerja karyawan pemasaran Bank Umum Syariah di Jawa Barat adalah sebesar 4\% dan pengaruh komitmen organisasional terhadap kinerja karyawan secara tidak langsung ialah senilai 5,9\%. Artinya sebesar 4\% kinerja karyawan pemasaran Bank Umum Syariah di Jawa Barat dipengaruhi langsung oleh komitmen organisasional dan senilai 5,9\% berdampak tidak langsung lewat penerapan nilai-nilai Islami. Total pengaruh komitmen organisasional terhadap kinerja karyawan pemasaran Bank Umum Syariah di Jawa Barat adalah sebesar 9,9\% dengan angka positif. Berarti pegawai yang mempunyai komitmen organisasional yang kuat maka akan berdampak pada peningkatan kinerja karyawan itu sendiri yang semakin baik. Oleh sebab itu, secara keseluruhan kinerja karyawan pemasaran Bank Umum Syariah di Jawa Barat dipengaruhi oleh komitmen organisasional sebesar 9,9\%. Sedangkan 90,1\% sisanya diakibatkan faktor lainnya yang bukan merupakan scope dari penelitian ini, seperti kompensasi, kepemimpinan, kepuasan kerja, lingkungan kerja dan sebagainya.

Economica: Jurnal Ekonomi Islam - Volume 9, Nomor 1 (2018) http://journal.walisongo.ac.id/index.php/economica 
Usep Deden Suherman

\section{Simpulan}

Hasil penelitian tentang pengaruh penerapan nilai-nilai Islami dan komitmen organisasional terhadap kinerja karyawan pemasaran Bank Umum Syariah di Jawa Barat dapat disimpulkan sebagai berikut. Pertama, terdapat pengaruh penerapan nilai-nilai Islami pada kinerja karyawan pemasaran Bank Umum Syariah di Jawa Barat. Hal ini menunjukkan bahwa penerapan nilai-nilai Islami yang baik pada karyawan dapat membantu peningkatan kinerja karyawan. Kedua, terdapat pengaruh komitmen organisasional pada kinerja karyawan pemasaran Bank Umum Syariah di Jawa Barat. Oleh sebab itu, pegawai yang mempunyai komitmen organisasional yang kuat dapat meningkatkan kinerja karyawan. Ketiga, penerapan nilai-nilai Islami dan komitmen organisasional memiliki dampak secara simultan pada kinerja karyawan pemasaran Bank Umum Syariah di Jawa Barat. Hal ini menggambarkan bahwa penerapan nilai-nilai Islami dan komitmen organisasional secara simultan dapat meningkatkan kinerja karyawan pemasaran Bank Umum Syariah di Jawa Barat. Keempat, nilai-nilai Islami mempunyai dampak yang lebih besar pada peningkatan kinerja karyawan pemasaran Bank Umum Syariah di Jawa Barat, sehingga organisasi perlu menjaga dan bahkan meningkatkan penerapan nilai-nilai Islami dalam perusahaan untuk mendukung kinerja organisasi.

Dari hasil penelitian mengenai pengaruh penerapan nilai-nilai Islami dan komitmen organisasional terhadap kinerja karyawan pemasaran Bank Umum Syariah di Jawa Barat, penulis menyarankan hal-hal sebagai berikut. Pertama, harus ada pengawasan dari pemerintah dan lembaga terkait atas penanaman nilai-nilai Islami di bank syariah. Kedua, mengoptimalkan lagi kinerja karyawan terutama dari berbagai aspek seperti sikap dan perilaku. Oleh sebab itu, diperlukan perhatian dalam pimpinan sebagai pemangku kebijakan untuk menanamkan nilai-nilai dan perilaku Islami. Ketiga, hasil penelitian menunjukkan bahwa penerapan nilai-nilai Islami memiliki pengaruh terhadap kinerja karyawan pemasaran Bank Umum Syariah di Jawa Barat. 
Oleh sebab itu, maka penerapan nilai-nilai Islami perlu direalisasikan dalam bentuk sebuah prosedur kerja dalam mendukung pekerjaan. Keempat, dikarenakan hasil riset menggambarkan bahwa komitmen organisasional berpengaruh terhadap kinerja karyawan maka para pimpinan perlu menjaga dan memelihara loyalitas karyawan melalui berbagai kebijakan yang ditujukan untuk kesejahteraan karyawan.

\section{Daftar Pustaka}

Abdi, Mohamed Farah, Siti Fatimah Dato' Wira Muhamad Nor, and Nor Zuhairatun Md. Radzi. 2014. "The Impact of Islamic Work Ethics on Job Performance and Organizational Commitment." In Proceedings of 5th Asia-Pacific Business Research Conference, 1-12. Kuala Lumpur Malaysia.

Abrahem. 2001. "Relationship and Influence between The Values of The Individual and Organizations in Building An Ethic of The Profession from The Perspective of Contemporary Thought and Islami." Paper Presented at the Third Forum for The Development of Human Resources, Human Resource Development Strategies: Perspectives and Challenges.

Al-Aidaros, Al-Hasan, Faridahwati Mohd. Shamsudin, and Kamil Md. Idris. 2013. "Ethics and Ethical Theories From an Islamic Perspective." International Journal of Islamic Thought 4.

Arslan, M. 2005. Is ve Meslek Ahlaki (Business and Professional Ethics). Ankara: Siyasal yayinevi.

Awan, Khurram Zafar, Mussawar Abbas, Ibn-e-Waleed Qureshi, and Hurram Shahzad. 2014. "Exploring the Relationship between Islamic Work Ethics, Employee Work Performance and the Mediation Role of Organizational Commitment." J. Asian Dev. Stud 3 (3).

Baek, Jong Hu. 2012. "The Impact of Transactional and Transformational Leadership on Organizational Commitment in Major League Baseball." Florida: St. Thomas University.

Beekun, Rafik I., and Jamal A. Badawi. 2005. "Balancing Ethical Responsibility among Multiple Organizational Stakeholders: The Islamic Perspective."

Economica: Jurnal Ekonomi Islam - Volume 9, Nomor 1 (2018) 
Journal of Business Ethics 60 (2). Kluwer Academic Publishers: 131-45. https://doi.org/10.1007/s10551-004-8204-5.

Bernardin, H. John, and Joyce E. A. Russell. 2010. Human Resources Mangement: An Experiental Approach. 5th ed. New York: McGraw-Hill Inc.

Chui, Josep. 2007. "Assessing the Extent to Which Career Development Impacts Employee Commitment: A Case Study of the ICT Industry in Hong Kong." In Australasian Conference on Information Systems. Australia: University of South Australia Adelaide SA.

Dixon, Tommy. 2012. "The Relationship of Organizational Commitment and Transformational Leadership Use in Project Managers."

Greenberg, Jerald. 2005. Managing Behavior in Organizations. 4th ed. New Jersey: Pearson Prentice Hall.

Hadisi, Mitra. 2014. "The Effect of Islamic Work Ethics on The Performance Result of Muslim Employees of Marketing Sector in The Multinational Companies." International Journal of Organizational Leadership 3 (1). Industrial Management Institute: 31-40. https://doaj.org/article/f8f040a5f529467ca6d00f68a689a976.

Hafidhuddin, and Hendri Tanjung. 2013. Manajemen Syari'ah Dalam Praktik. Jakarta: Gema Insani Press.

Hafiz AZ. 2017. "Relationship between Organizational Commitment and Employee's Performance Evidence from Banking Sector of Lahore." Arabian Journal of Business and Management Review 7 (3): 1-7.

Hashi, Abdurezak A. 2011. "Islamic Ethics: An Outline of Its Principles and Scope." Revelation and Science 1 (3): 122-30.

Kreitner, Robert, and Angelo Kinicki. 2005. Organizational Behavior. 5th ed. Jakarta: Salemba Empat.

Landry, Guylaine, and Christian Vandenberghe. 2009. "Role of Commitment to the Supervisor, Leader-Member Exchange, and Supervisor-Based SelfEsteem in Employee-Supervisor Conflicts." The Journal of Social $\begin{array}{llll}\text { Psychology } & 149 & \text { (1). } & \text { Heldref: }\end{array}$ https://doi.org/10.3200/SOCP.149.1.5-28.

Limsila, Kedsuda, and Stephen O. Ogunlana. 2008. "Performance and Leadership Outcome Correlates of Leadership Styles and Subordinate 
Pengaruh Penerapan Nilai-nilai Islami...

Commitment." Engineering, Construction and Architectural Management 15 (2). Emerald Publishing Limited: 164-84. https://doi.org/10.1108/09699980810852682.

Luthans, Fred. 2008. Organizational Behaviour. 11th ed. New York: McGrawHill International.

Mathis, Robert L, and John H Jackson. 2006. Human Resources Management. Jakarta: Salemba Empat.

McShane, Steven Lattimore, and Mary Ann Young Von Glinow. 2005. Organizational Behaviour: Emerging Realities for the Workplace Revolution. 2nd ed. Columbus: Mc Graw Hill.

Memari, Negin, Omid Mahdieh, and Ahmad Barati Marnani. 2013. “The Impact of Organizational Commitment on Employees Job Performance: A Study of Meli Bank." Interdisciplinary Journal of Contemporary Research in Business 5 (5): 164-71.

Meyer, John P., David J. Stanley, Lynne Herscovitch, and Laryssa Topolnytsky. 2002. "Affective, Continuance, and Normative Commitment to the Organization: A Meta-Analysis of Antecedents, Correlates, and Consequences." Journal of Vocational Behavior 61 (1): 20-52. https://doi.org/10.1006/jvbe.2001.1842.

Musrin, M. 2004. Sistem Nilai Dan Pandangan Hidup Serta Relasinya Dengan Ilmu Pengetahuan. Jakarta: Wardah.

Nusantara, Lembaga Pengkajian Kebudayaan. 2000. Kamus Besar Ilmu Pengetahuan. Jakarta: Golo Riwu.

Ooi, Keng Boon, and Veeri Arumugam. 2006. "The Influence of Corporate Culture on Organizational Commitment: Case Study of Semiconductor Organizations in Malaysia." Sunway Academic Journal 3. Sunway University College: 99-115. http://eprints.sunway.edu.my/31/.

Padmawati, Syarah. 2007. "Kajian Fisiologis Dan Nilai-Nilai Islam Dalam Hikayat Raja Rahib." Universitas Negeri Semarang.

Qureshi, Javeria Ashfaq, Khansa Hayat, Mehwish Ali, and Nosheen Sarwat. 2011. "Impact of Job Satisfaction and Organizational Commitment on Employee Performance, Evidence from Pakistan." Interdisciplinary Journal Of Contemporary Research In Business 3 (4).

Rivai, and Buchari. 2009. Islamic Economy. Jakarta: PT. Bumi Aksara.

Economica: Jurnal Ekonomi Islam - Volume 9, Nomor 1 (2018) 
Robbins, Stephen P., and Timothy A. Judge. 2009. Organizational Behavior. 13th ed. United Kingdom: Pearson International Edition.

Sakinah, Mat Zin, and Ahmad Azrin Adnan. 2016. “How Do Intellectual Capital and Islamic Values Relate to Small Business Performance? A Conceptual Framework." Journal of Applied Environmental and Biological Sciences 6 (3S): 42-49.

Salahudin, Shahrul Nizam bin, Siti Sarah binti Baharuddin, Muhammad Safizal Abdullah, and Abdullah Osman. 2016. "The Effect of Islamic Work Ethics on Organizational Commitment." Procedia Economics and Finance 35 (January). Elsevier: 582-90. https://doi.org/10.1016/S22125671(16)00071-X.

Salem, Zaneb Omer, and Syed Omar Syed Agil. 2012. "The Effects of Islamic Individuals' Ethics on Organizational Commitment of Employees in Libyan Public Banks." Australian Journal of Basic and Applied Sciences 6 (7): $260-70$.

Shafique, Muhammad Nouman, Muhammad Haseeb, Naveed Ahmad, Mahboob Khurshid, and Hussain Ahmad. 2015. "The Influence of Islamic Work Ethics on Job Satisfaction and Organization Commitment." Journal of Marketing and Consumer Research 14: 23-28.

Tolentino, Rebecca C. 2013. "Organizational Commitment and Job Performance of the Academic and Administrative Personnel." International Journal of Information Technology and Business Management 15 (1): 51-59.

Wahab, Mastura Ab. 2012. "The Impact of Islamic Work Values on Employees' Job Performance in Malaysia." University of Canberra.

Wahyudi, Amin. 2015. "The Influence of Organizational Commitment and Islamic Work Ethic Toward Job Performance of Teaching Staff At Universities In Surakarta With Institutional Base as a Moderator Variable." In Proceeding Internasional Seminar. Vol. 0. http://ejurnal.unisri.ac.id/index.php/pasca/article/view/1104.

Yahchouchi, George. 2009. 'Employees' Perceptions of Lebanese Managers' Leadership Styles and Organizational Commitment." International Journal of Leadership Studies 4 (2): 127-40.

Yaken. 2006. What Is the Meaning of My Belong to Islam. Beirut: Darul AlRessalh Publication. 
Pengaruh Penerapan Nilai-nilai Islami...

Yousef, Darwish Abdulrahman. 2001. "Islamic Work Ethic - A Moderator between Organizational Commitment and Job Satisfaction in a Crosscultural Context." Personnel Review 30 (2). MCB UP Ltd: 152-69. https://doi.org/10.1108/00483480110380325. 
